\title{
The Impact of Sport Financial Sponsorship on Brand Equity and Performance: Structural Equation Modeling (SEM) Approach
}

\author{
${ }^{1}$ Mohammad Zarei Mahmoudabadi ${ }^{*},{ }^{2}$ Mohammad Keshtidar, ${ }^{2}$ Seyed Mohammad \\ Javad Razavi \\ ${ }^{1}$ Department of Management, Meybod University, Meybod, Iran. ${ }^{2}$ Department of Sport Management, \\ Faculty of Sport Sciences, Ferdowsi University of Mashhad, Mashhad, Iran.
}

Submitted 07 November 2018; Accepted in final form 18 February 2019.

\begin{abstract}
Background. Sport financial sponsorship can offer sport marketers the opportunities to address new audiences and enhance brand equity and companies' performance. Objectives. The purpose of the current study was to develop a model for the role of sport financial sponsorship on brand equity of Yazd ceramic and tile companies. Methods. The current study was conducted with a survey method. Standard sport financial sponsorship and brand equity questionnaires were used as measurement tools to assess the subjects. Data analysis was conducted both descriptively and inferentially. Results. The results of the data analysis revealed that sport financial sponsorship has a significant positive effect on brand equity, and brand equity, in turn, has a significant positive impact on companies' performance. Conclusion. It seems that due to the nature of the exercise and its effectiveness in promoting the sponsor company, it has a positive influence on developing brand equity of companies. It was found that proper behavior of members of the board of directors of companies towards their brand facilitates this process.
\end{abstract}

KEY WORDS: Sports Financial Sponsorship, Brand Equity, Performance, Ceramic and Tile Companies.

\section{INTRODUCTION}

Sport financial sponsorship (SFS) can provide marketers with opportunities to improve brand awareness and brand image [1]. This is one of the reasons why sports financial sponsorship has become increasingly popular as a marketing tool in recent years and it is one of the most commonly-used tools particularly to promote their products [2]. Market research results have shown the potential of sports financial sponsorship in improving people's awareness of products [3]. Also, the past three decades have witnessed a growing literature and the role of management in the improvement of brands $[4,5]$. One of the important points of this work has been related to concept of brand equity
(BE). BE is considered as a concept both in academic research and business practice, as successful brands give marketers competitive advantage [6]. Yoo and Donthu (2001) defined $\mathrm{BE}$ as "a multidimensional construct consisting of perceived quality, brand image, and brand loyalty" [7]. Therefore, taking care of brand equity, as an added value which brings a trademark to a product, is considerably constructive [8]. There is no doubt that opportunities with higher BE are more likely to improve companies' relationships with buyers [9]. Webster and Keller (2004) also argued that a strong brand helps sellers to reinforce their control over the relational exchange with buyers

*. Corresponding Author:

Mohammad Zarei Mahmoudabadi, Assistant Professor

E-mail: zarei.m@meybod.ac.ir 
[10]. Creating strong brand equity is the goal of many companies since the brand is the most valuable asset to every company. Based on a powerful brand, firms can set higher prices for their products, create better business leverage, increase their sales and profit margins, and reduce their vulnerability against competitors [11].

Previous studies have paid more attention to $\mathrm{BE}$ role in other entities such as other companies [9] and banks [6], while less attention has been paid to the role and development of BE in ceramic and tile companies. As in previous studies, the impact of sports financial sponsorship on brand equity $[1,12]$, the influence of sports financial sponsorship on employees' perceptions of recommending the company to others and employee retention [13], and the impact of sports sponsorship on word of mouth [14] have been examined.

\section{Theoretical Background}

Brand equity, as a concept, evolved in the late 80 s and has become one of the most important marketing concepts in recent years $[11,15]$. A number of studies have offered certain models concerning sport financial sponsorship industry $[1,16,17]$. These studies contributed to our knowledge of the effects of sport financial sponsorship on the sponsor's brand equity. The Tsordia, Papadimitriou, and Parganas (2018) extended Aaker's model in the sports sponsorship context and highlights the influential role of perceived quality and brand engagement in driving sport team fans to form brand loyalty and purchase sponsor's product [1]. Other studies have also emphasized the effect of sports sponsorship on brand equity [2, 12]. In this regard, Ghani et al. (2018) conducted a study entitled "The relationship between sports clubs and sponsors" and found a positive significant relationship between event sponsorship in sports and brand equity [12]. In another study, Florian (2017) concluded that sports sponsorship has been effective in developing the brand equity of Puma [2]. Further, Chebli and Gharbi (2014) conducted a study under the title of "The Impact of the Effectiveness of Sponsorship on Image and Memorizing: Role of Congruence and Relational Proximity". Their literature review demonstrated that the effectiveness of the sponsorship can be analyzed through image and memorization [18]. Since brand equity is a key factor in marketing, and as a valuable brand can promote the employees' trust to the company, the brand is regarded as a precious asset to a commercial corporate [19]. Hence, the current study aimed at analyzing the significance of this issue based on the following hypotheses:

$H_{1}$ : Sports sponsorship positively influences development of brand equity of ceramic and tile companies.

Sports sponsorship is an effective tool for companies to promote their brand [20]. Also, it offers unique opportunities for operationalizing brand strategy [10]. Previous research highlights the power of sponsorship to build brand equity. In this regard, using the constructs of Aaker's (1991) model, two studies have so far explored the effects of sports sponsorship on the brand [21, 22]. The former examined the managers' views of the effect of various sponsorship programs on building brand equity over time, including the dimensions of brand awareness, the image of quality and brand loyalty. On the other hand, the latter inspected how managers of the sponsoring companies perceive the effects of different levels of sponsorship on brand equity. However, while both studies highlighted the strong relationship between sport financial sponsorship and the four components of brand equity (brand awareness, associations, loyalty, and perceived quality), they examined the sponsorship-branding relationship from a managers' point of view $[11,15]$. On the other hand, Wagner et al. (2018) conducted a study entitled "improving service-center employees' performance by means of a sport financial sponsorship" and showed that sports sponsorship positively affects employees' perceptions of their ability to communicate with customers, to recommend the company to others, to engage in teamwork, as well as employee retention. This suggests that the sponsorship has had a significant and positive impact on company performance [13]. Similarly, Buil, de Chernatony, and Martínez (2011) conducted a study entitled "The role of advertising and sales promotion in creating brand equity". For this purpose and in order to assess advertisements, they considered advertising costs and consumers' attitudes towards advertising. Their findings suggested that consumers' attitudes towards the ads play a key role in influencing the dimensions of brand equity [23]. Also, Tsiotsou, Alexandris, and Bettina Cornwell (2014) indicated that sponsor brand 
familiarity explains part of the variance in sponsor brand image and word of mouth [14]. Word of mouth is a positive recommendation to others about the brand of the sponsor. In another research, Misener and Doherty (2014) conducted a study entitled "the relationship between private sports clubs and sponsors." Their results revealed that financial support affects plans and performance of sports clubs. Also, the proper functioning of sports clubs has a significant relationship with financial support by sponsors [24]. Further, in another study, Naidenova, Parshakov, and Chmykhov (2016) concluded that financial support of Europe's premier leagues is a kind of capital investment and affects the performance of sponsor corporate [25]. The analysis of the factors affecting sponsorship shows that the companies whose members and shareholders are aware of financial assumptions and support aspects are more likely to become a sponsor.

$\mathrm{H}_{2}$ : Sport financial sponsorship is positively affected by organizational behavior of the brand in of ceramic and tile companies.

$H_{3}$ : Sport financial sponsorship is positively affected by brand satisfaction of ceramic and tile companies.

$H_{4}$ : Sport financial sponsorship is positively affected by intention to stay of ceramic and tile companies.

$H_{5}$ : Sport financial sponsorship is positively affected by positive recommendation about the brand of ceramic and tile companies.

Based on the formulated hypotheses, a conceptual model is proposed as presented in Figure 1.

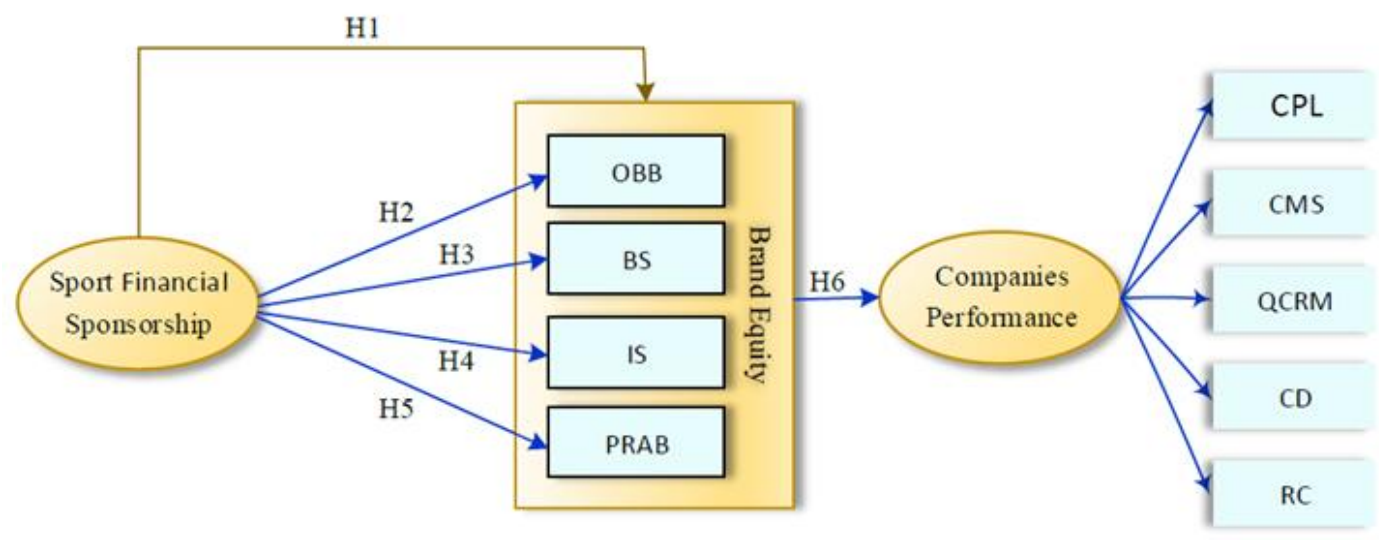

Figure 1. Research conceptual model and the impact of antecedent factors on brand equity.

Performance measurement is the process of collecting, analyzing, and reporting information regarding the performance of an individual, organization, or company. It plays a key role for achieving sustainable development in the competitive environment [26]. It is a managerial concept with a long history in various topics of management science, and can involve studying processes or strategies within organizations, to see whether outputs are in line with what was intended or should have been achieved [27]. Also, brand equity as the added value that a brand name gives to a product, is represented as total customer value [28]. In today's global business-to-business (B2B) environment, successfully establishing prominent $\mathrm{BE}$ has been considered a foundation for sustaining business performance (BP) [28-30]. Marketing management topics contain many studies that have examined the concept of BE and BP. Wang and Sengupta (2016), García-Osma, Villaseñor, and Yaguie (2015), and Felício et al. (2014) have conducted studies to determine how BE results in BP [31-33]. Narteh (2018) investigated a study on the relationship between $\mathrm{BE}$ and financial performance. They found that service quality, brand association, brand loyalty, and brand relevance predicted financial performance of the retail banks [28]. Also, Chen and Chang (2008) showed that brand equity is a key factor in marketing and that a valuable brand can enhance the trust of customers when purchasing goods and services [19]. As a result, brand equity can be regarded as a valuable and key asset for a firm performance. Accordingly, the sixth hypothesis is proposed as follows:

H6: Brand equity is positively associated with companies' performance (CP). 
Now, according to aforementioned points, a comprehensive model will be presented concerning the effects of sport financial sponsorship on brand equity from the perspective of board members of ceramic and tile companies in the Yazd province (one of the most developed provinces in Iran).

\section{MATERIALS AND METHODS}

Methodology. Considering the purpose, the current research is an applied study, and according to the nature of the study, it is regarded as a survey study. The required data for the study were obtained using a questionnaire.

Participants. Research population included all members of the board of Yazd ceramic and tile companies. Specifically, the focus of this study was sports sponsorship of Yazd ceramic and tile companies for a football professional club. According to Industry, Mine and Trade Organization of Yazd, in 2017, there were 65 active tile companies in Yazd. The survey link was e-mailed to 780 companies' managers and employees where 320 usable responses were obtained for an effective response rate of $41 \%$. Adopting the ratio of indicators to latent variables criterion [34], this sample is considered adequate for structural equation modeling (SEM)-based analysis.

Instrumentation: The sports financial sponsorship (SFS) questionnaire by Bahraini and Ziaei (2011) [35], companies' performance (CP) questionnaire by Akroush et al. (2011) [36], and the standard questionnaire of $\mathrm{BE}$ by King and Grace (2008) [37] were the main measurement instruments in the current study. The sport financial sponsorship (SFS) standard questionnaire consists of four factors: the length of SFS (LS), budget spent on SFS (BSS), active management for SFS (AMS), and quality of sports clubs to support (QSCS). Also, the BE standard questionnaire consists of four factors: organizational behavior brand (OBB), brand satisfaction (BS), intention to stay (IS), and positive recommendation about the brand (PRAB) components. In addition, all the three questionnaires used a 5-degree Likert scale.

Validity and Reliability of the Tools. The validity of the questionnaires was confirmed by 10 professors of sports management. Also, the reliability of the questionnaires using Cronbach's alpha coefficient was determined to be $0.92,0.88$, and 0.96 , respectively.

Statistical Analysis. Data analysis was conducted both descriptively and inferentially. In order to prepare the model in the current study, the structural equation modeling technique was used with the help of Smart PLS software and SPSS $_{22}$.

\section{RESULTS}

Based on the results, most of the subjects were older than 36 years, had a diploma in education, had 9 to 15 years of experience, and expected to receive the facilities from the government. Further, the minimum age of the sample was 26 to 30 years old, had MA/MS degrees, with more than 24 years of experience (Table 1).

The results of the evaluation of the model fitness indicated that CV-Red and CV-Com had a positive value, indicating the appropriate fitness for the model. Also, CR and AVE for each of the six latent variables of the model had an appropriate value. R-Square constants were greater than 0.5 and 0.7 for all the latent variables of the model, which are appropriate values. The findings indicate that the fit is suitable for the model (Table 2). Based on the results shown in Figure 2 and 3, and Table 3, it can be said that for the entire Brand Equity, companies' performance variables and sport financial sponsorship of all indices have created a significant weight and can have a significant factor loading at a confidence level of $99 \%$.The relationship between latent variables in the structural equation model is of direct effect type. Direct effect, which is one of the components of structural equation modeling, shows a directed relationship between two variables. Since the hypotheses of this study indicate the relationships between latent variables of the model, the findings from this study suggest that all six research hypotheses, according to collected data, and also considering the results of the research model, have been confirmed (Table 4). 
Table 1. Frequency distribution and percentage of managers and employees based on demographic features

\begin{tabular}{|lccc|}
\hline Features & Frequency & Percentage & Total frequency \\
Age & & & 320 \\
26 to 30 & 14 & 4 & \\
31 to 35 & 28 & 15 & \\
$\quad$ Older than 35 years & 258 & 81 & 320 \\
Education & 58 & 18 & \\
$\quad$ Less than a high school diploma & 138 & 43 & \\
$\quad$ Diploma & 48 & 15 & \\
Associate Degree & 66 & 21 & 320 \\
Bachelor's degree & 8 & 3 & \\
MA/MS & & & \\
Experience & 118 & 37 & 320 \\
Less than 8 years & 182 & 58 & \\
9-15 & 20 & 5 & \\
16-24 & 0 & 0 & \\
More than 24 years & & & \\
Facilities and expectations required to support & 244 & 76 & \\
Government & 40 & 13 & \\
Radio and television & 8 & 2 & \\
football Federation & 28 & 9 & \\
$\quad$ None & & & \\
& & & \\
\hline
\end{tabular}

Table 2. Model fitting indices

\begin{tabular}{|lcccc|}
\hline Variable & AVE CR R & RV-RedCV-ComCronbach's Alpha \\
Sport Financial Sponsorship (SFS) & $0.800 .94-$ & 0.65 & 0.65 & 0.92 \\
Brand Equity (BE) & 0.570 .960 .62 & 0.34 & 0.53 & 0.96 \\
Brand Equity (BE) & & & & \\
$\quad$ Organizational Behavior brand (OBB) & 0.710 .940 .49 & 0.34 & 0.61 & 0.93 \\
$\quad$ Brand satisfaction (BS) & 0.640 .890 .47 & 0.29 & 0.47 & 0.85 \\
$\quad$ Intention to stay (IS) & 0.720 .910 .53 & 0.37 & 0.52 & 0.87 \\
$\quad$ Positive recommendation about the brand (PRAB) & 0.660 .880 .59 & 0.38 & 0.44 & 0.82 \\
Companies' performance & 0.710 .840 .48 & 0.41 & 0.39 & 0.88 \\
\hline
\end{tabular}

CR: Composite Reliability; CV-Red: CV-Redundancy; CV-Com: CV-communality; AVE: Average Variance Extracted

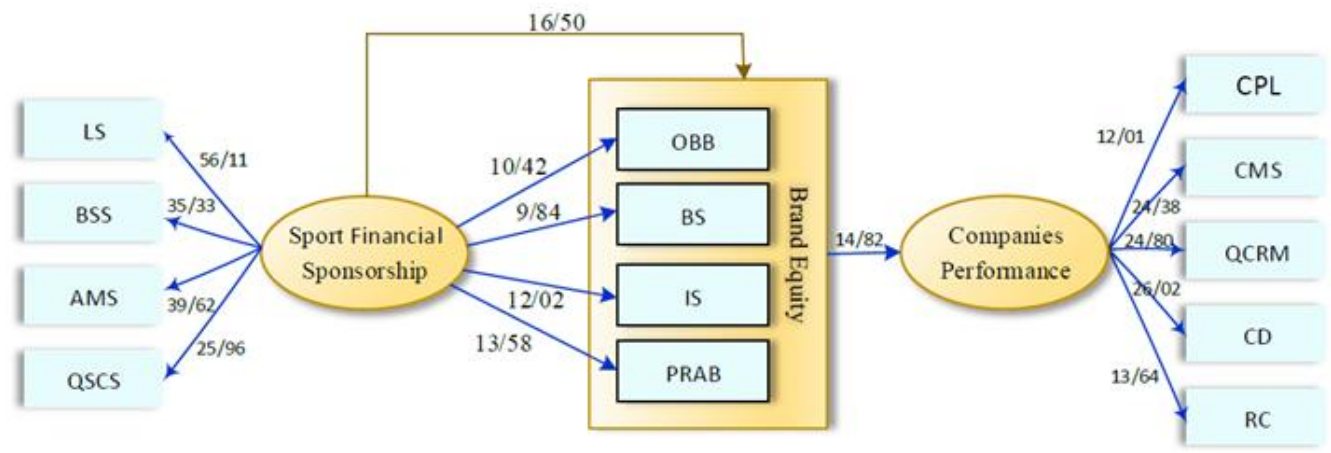

Figure 2. Conceptual Model of the Research with the significance of the coefficients (t-value).

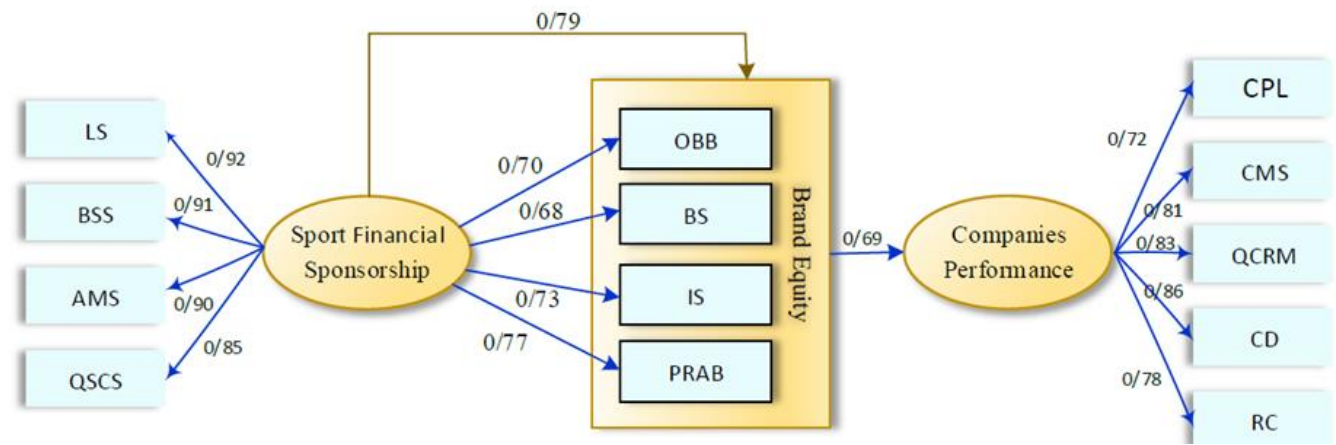

Figure 3. Conceptual model of research with standardized coefficients and factor loadings. 
Table 3. Estimated factor loadings and their significance level

\begin{tabular}{|lccc|}
\hline Observed variables & \multicolumn{3}{c|}{ Factor Loadingst-ValueSignificance level } \\
Sport Financial Sponsorship (SFS) & 0.92 & 56.11 & 0.001 \\
$\quad$ The length of Sport Financial Sponsorship (LS) & 0.91 & 35.33 & 0.001 \\
$\quad$ Budget Spent on Sport Financial Sponsorship (BSS) & 0.90 & 39.62 & 0.001 \\
$\quad$ Active management for Sport Financial Sponsorship (AMS) & 0.85 & 25.96 & 0.001 \\
$\quad$ Quality of sports clubs to support (QSCS) & & & \\
Brand Equity (BE) & 0.93 & 91.42 & 0.001 \\
$\quad$ Organizational Behavior brand (OBB) & 0.93 & 58.59 & 0.001 \\
$\quad$ Brand satisfaction (BS) & 0.91 & 44.52 & 0.001 \\
$\quad$ Intention to stay (IS) & 0.88 & 33.37 & 0.001 \\
$\quad$ Positive recommendation about the brand (PRAB) & 0.72 & 12.01 & 0.001 \\
Companies Performance & 0.81 & 24.38 & 0.001 \\
$\quad$ Club's profitability level & 0.83 & 24.80 & 0.001 \\
$\quad$ Club's market share & 0.86 & 26.02 & 0.001 \\
$\quad$ Quality of Customer Relationship Management & 0.78 & 13.64 & 0.001 \\
\hline Customer durability & & & \\
\hline Competitive position relative to competitor (other sport clubs)
\end{tabular}

Table 4. Direct effects, $t$-Value, and the hypothesis result

\begin{tabular}{lcccc|}
\hline Hypotheses & Standardized coefficient $(\boldsymbol{\beta})$ t-valueSignificance levelThe result of the researcher's hypothesis \\
$\mathrm{SFS} \rightarrow$ BE & 0.79 & 16.50 & 0.001 & Confirmed \\
$\mathrm{SFS} \rightarrow$ OBB & 0.70 & 10.42 & 0.001 & Confirmed \\
SFS $\rightarrow$ BS & 0.68 & 9.84 & 0.001 & Confirmed \\
SFS $\rightarrow$ IS & 0.73 & 12.02 & 0.001 & Confirmed \\
SFS $\rightarrow$ PRAB & 0.77 & 13.58 & 0.001 & Confirmed \\
BE $\rightarrow$ CP & 0.69 & 14.82 & 0.001 & Confirmed \\
\hline
\end{tabular}

\section{DISCUSSION AND CONCLUSION}

This is one of the first papers to examine how sport financial sponsorship contributes to brand equity and business performance. It will add significant value for the industry to enhance their brand equity and business performance though sport financial sponsorship practices.

In recent years, companies have faced increasing problems for reaching fragmented consumer markets with their traditional marketing instruments such as advertising and sales promotions. This is the reason why sponsorship has become increasingly popular as a marketing tool and as one of the marketing communication elements, sports financial sponsorship (SFS) including providing resources (financial, human, and material) by an organization or a company (pro sports) directly for a supported entity (such as a gym, sports personalities, sports event and so on). Through supported activities, return on investment is realized for the organization or company. Support, companies, and financial assistance, or non-financial contribution are among the strategies to achieve business objectives, and indeed, an indirect component of marketing. In addition to improving the company's brand value, this also leads to the benefit of society. Thus, given the importance of this issue, the researcher tried to offer a model concerning the effect of SFS on $\mathrm{BE}$ from the perspective of ceramic and tiles companies' managers. The findings based on structural equation modeling (SEM) indicated that SFS has a significant positive impact on BE of ceramic and title companies. In other words, if the managers of these companies support athletics and professional sports, they will lead to increased brand equity of their company. This result of this study was congruent with the findings of past studies by Shank (2014), Buil, de Chernatony, and Martínez (2013), Misener and Doherty (2014), Florian (2017), and Ghani et al. (2018) [2, 12, 23, 24, 38]. Specifically, Shank (2014) stated that athletes can build up a prompt association with the brand, as they are very famous among the customers [38]. Thus, sports financial sponsorship has a positive influence on the brand equity of a company and is very effective for its augmentation. Overall, considering the effective role of SFS in promoting the brands of companies, SFS is gaining increasing attention.

Indeed, SFS is considered as one of the modern tools of marketing communication in the current age through which one can establish effective communication with target customers and use their passions and emotions towards their favorite sports unit to enhance the $\mathrm{BE}$ of the company. Thus, to enhance their $\mathrm{BE}$ and gain competitive privilege through SFS, and thus distinguish their brand from the competitors, the 
companies should practice this in a unique way. One of the factors that determines the uniqueness of SS is continuity and sustainability in supporting a sports team or unit for a fixed long time. Hence, it is necessary that managers take measures to develop their BE by considering the dimensions of SFS determined in this study, such as the magnitude of funds spent on SS and the quality of the club they choose to support.

Another finding of the study revealed that sports financial sponsorship has significant positive effects on components of the special value of tile and ceramic companies. Indeed, if these companies support sports events, higher satisfaction can be generated in employees and managers, leading to positive recommendation for the brand outside the organization. Special value is what a particular investor or group of investors believe the assets to be worth because of some unique advantages to be realized from the asset acquisition. Special value is very different from the business market value which disregards any special or synergistic benefits to the investor and requires only the presence of a hypothetical willing buyer and seller parties. Indeed, the difference between the market value and special value is what creates interest for these synergistic investors. Special value is one of the several bases of value defined under the International Valuation Standards. This finding was in line with those of previous studies such as Aaker (2012) and Naidenova, Parshakov, and Chmykhov (2016) $[11,25]$. Therefore, one way to promote the special value of companies is through developing sports financial sponsorship by the managers, so that their brand will positively be recognized thanks to the popularity of sports events in the society. Further, the sports industry, with a stimulating factor such as holding major sports competitions, has the possibility of taking advantage of advertising opportunities and has made the managers of tile companies show desired behavior to promote their company's brand. Therefore, the use of SS tool by managers of tiles companies can play a significant role in promoting these companies' brands in the eyes of society.

Also, the study findings suggest that BE had a positive and significant impact on the $\mathrm{BP}$ of ceramic and tile companies. According to the literature, this finding was in line with that of García-Osma, Villaseñor, and Yagüe (2015) [32], where it was determined according to previous research that brand equity development has a significant impact on BP [28, 31]. Also, Narteh (2018) showed that there is a relatively strong positive relationship between $\mathrm{BE}$ and financial performance [28]. It is proven that by being aware of the features and dimensions of BP, ceramic and tile companies managers can be more successful in applying more effective, more powerful, and more robust brand strategies and the BP of ceramic and tile companies, such as the creation and development of competitive advantage over other ceramic and tile companies, development of ceramic and tile companies customers, the market share, and the profits of ceramic and tile companies enhance, they will increase $\mathrm{BE}$ of ceramic and tile companies.

The paper suggests that managers can enhance business performance and brand equity by enhancing their sport financial sponsorship. Managers of industry can develop corresponding strategies based on the findings to achieve their particular performance goals. This research takes its lead from and extends prior study, thus providing a deepened understanding of the role of sport financial sponsorship in ceramic and tile companies settings

As with any other study, the current research also suffered certain limitations. Relatively hard access and non-responsiveness of some managers of tile and ceramic companies in Yazd Province were among the major problems. Another limitation was concerned with a lack of control over all mediator variables in managers' responses such as their mental and emotional state while answering the questions or how much they cared about the accuracy of their answers. Finally, the third limitation was related to the fact that in spite of the broad range of manufacturing companies in Yazd Province, the current study has examined only a specific field that is tile and ceramic companies. However, different results may be obtained in other industries.

Furthermore, future researchers are recommended to examine the effect of sport financial sponsorship on other aspects of a brand such as brand identity, brand loyalty, brand image, and brand performance. In addition to the recommendations given above, the author suggests paying further attention to green brand equity in ceramic and tile companies. Since, by identifying the potential needs of the consumers, 
marketers today have established a type of marketing called Green Marketing, one of the most important issues assisting in company branding and achieving sustainable competitive advantage. Due to the environmental problems such as global warming and environmental pollution by companies, green branding and its equity have received a great deal of attention, which can offer considerable findings regarding the promotion of the companies' brand under study.

\section{APPLICABLE REMARKS}

- According to the present study, tile and ceramic companies are recommended to promote the special value of their brands through supporting professional sports clubs and championship events.

\section{REFERENCES}

1. Tsordia C, Papadimitriou D, Parganas P. The influence of sport sponsorship on brand equity and purchase behavior. J Strategic Market. 2018;26(1):85-105. doi: 10.1080/0965254X.2017.1374299

2. Florian S. The Effect of Sport Sponsorship on Brand Equity: Does the sponsorship of Usain Bold help Puma to increase their brand equity? Valkeakoski: Hame University of Applied Sciences; 2017.

3. Schlesinger T, Güngerich M. Analysing sport sponsorship effectiveness - the influence of fan identification, credibility and product-involvement. Int J Sport Manage Market. 2011;9(1-2):54-74. doi: 10.1504/IJSMM.2011.040257

4. Hankinson G. The measurement of brand orientation, its performance impact, and the role of leadership in the context of destination branding: An exploratory study. J Market Manage. 2012;28(78):974-99. doi: 10.1080/0267257x.2011.565727

5. Tilley C. Built-In Branding: How to Engineer a Leadership Brand. J Market Manage 1999;15(13):181-91. doi: 10.1362/026725799784870405

6. Yoganathan D, Jebarajakirthy $\mathrm{C}$, Thaichon $\mathrm{P}$. The influence of relationship marketing orientation on brand equity in banks. J Retail Consum Serv. 2015;26:14-22. doi: 10.1016/j.jretconser.2015.05.006

7. Yoo B, Donthu N. Developing and validating a multidimensional consumer-based brand equity scale. J Busin Res. 2001;52(1):1-14. doi: 10.1016/S0148-2963(99)00098-3

8. Farquhar PH. Managing brand equity. J Market Res. 1989;1(3):24-33.

9. Kim J-H, Hyun YJ. A model to investigate the influence of marketing-mix efforts and corporate image on brand equity in the IT software sector. Industrial Marketing Management. 2011;40(3):42438. doi: 10.1016/j.indmarman.2010.06.024

10. Webster FE, Keller KL. A roadmap for branding in industrial markets. J Brand Manage. 2004;11(5):388-402. doi: 10.1057/palgrave.bm.2540184

11.Aaker DA. Building Strong Brands: Simon \& Schuster UK; 2012. 400 p.

12. Ghani WSWA, Ma'amor H, Ramli N, Rashid NM. Assessing the Relationship Between Brand Equity Towards the Success of Sports Event Sponsorship: The Case of Local Running Event. Adv Sci Lett. 2018;24(4):2604-7. doi: 10.1166/asl.2018.11015

13. Wagner U, Hansen KR, Kristensen ML, Josty M. Improving service-center employees' performance by means of a sport sponsorship. Int J Sports Market Sponsorsh. 2018;20(1):43-60. doi: 10.1108/IJSMS-10-2017-0109

14. Tsiotsou RH, Alexandris K, Bettina Cornwell T. Using evaluative conditioning to explain corporate co-branding in the context of sport sponsorship. Int J Adv. 2014;33(2):295-327. doi: 10.2501/IJA33-2-295-327

15.Lane Keller K. Conceptualizing, Measuring, and Managing Customer-Based Brand Equity. J Market. 1993;57(1):1-22. doi: 10.1177/002224299305700101

16. Grohs R, Wagner UM, Vsetecka S. Assessing the Effectiveness of Sport Sponsorships - an Empirical Examination. Schmalenbach Busin Rev. 2004;56:119-38.

17. Smith G. Brand Image Transfer Through Sponsorship: A Consumer Learning Perspective. J Market Manage. 2004;20(3-4):457-74. doi: 10.1362/026725704323080498

18. Chebli L, Gharbi A. The Impact of the Effectiveness of Sponsorship on Image and Memorizing: Role of Congruence and Relational Proximity. Proc Soc Behav Sci. 2014;109:913-24. doi: https://doi.org/10.1016/j.sbspro.2013.12.564 
19. Chen C-F, Chang Y-Y. Airline brand equity, brand preference, and purchase intentions-The moderating effects of switching costs. J Air Transport Manage. 2008;14(1):40-2. doi: 10.1016/j.jairtraman.2007.11.003

20. Vredenburg J, Vredenburg H, Daellenbach K, Daellenbach U. Sport sponsorship, brand association and regulation: tobacco firms using classical conditioning theory to skirt regulation. Int J Public Law Pol. 2015;5(2):137-61. doi: 10.1504/IJPLAP.2015.071037

21. Cornwell TB, Roy DP, Steinard EAI. Exploring Managers' Perceptions of the Impact of Sponsorship on Brand Equity. J Adv. 2001;30(2):41-51.

22. Henseler J, Wilson B, Götz O, Hautvast C. Investigating the moderating role of fit on sports sponsorship and brand equity. Int J Sports Market Sponsorsh. 2007;8(4):34-42. doi: 10.1108/IJSMS08-04-2007-B005

23. Buil I, de Chernatony L, Martínez E. Examining the role of advertising and sales promotions in brand equity creation. J Busin Res. 2013;66(1):115-22. doi: 10.1016/j.jbusres.2011.07.030

24. Misener K, Doherty A. In support of sport: Examining the relationship between community sport organizations and sponsors. Sport Manage Rev. 2014;17(4):493-506. doi: https://doi.org/10.1016/j.smr.2013.12.002

25. Naidenova I, Parshakov P, Chmykhov A. Does football sponsorship improve company performance? Eur Sport Manage Q. 2016;16(2):129-47. doi: 10.1080/16184742.2015.1124900

26.Zarei Mahmoudabadi M, Azar A, Emrouznejad A. A novel multilevel network slacks-based measure with an application in electric utility companies. Energy. 2018;158:1120-9. doi: 10.1016/j.energy.2018.05.161

27. Azar A, Zarei Mahmoudabadi M, Emrouznejad A. A new fuzzy additive model for determining the common set of weights in Data Envelopment Analysis. J Intell Fuzzy Syst. 2016;30(1):61-9. doi: 10.3233/IFS-151710

28. Narteh B. Brand equity and financial performance: The moderating role of brand likeability. Market Intel Plann. 2018;36(3):381-95. doi: 10.1108/MIP-05-2017-0098

29. Keller KL. Understanding brands, branding and brand equity. Interact Market. 2003;5(1):7-20. doi: 10.1057/palgrave.im.4340213

30.Zeithaml VA, Lemon KN, Rust RT. Driving Customer Equity: How Customer Lifetime Value Is Reshaping Corporate Strategy: Free Press; 2001. 304 p.

31. Felício JA, Duarte M, Caldeirinha V, Rodrigues R. Franchisee-based brand equity and performance. Serv Ind J. 2014;34(9-10):757-71. doi: 10.1080/02642069.2014.905922

32. García-Osma B, Villaseñor N, Yagüe MJ, editors. Do brands matter in private firms? An empirical study of the association between brand equity and financial performance. International Marketing Trends Conference; 2015 January 22; Paris.

33. Wang H-MD, Sengupta S. Stakeholder relationships, brand equity, firm performance: A resourcebased perspective. J Busin Res. 2016;69(12):5561-8. doi: 10.1016/j.jbusres.2016.05.009

34. Marsh HW, Bailey M. Confirmatory Factor Analyses of Multitrait-Multimethod Data: A Comparison of Alternative Models. Appl Psychol Meas. 1991;15(1):47-70. doi: 10.1177/014662169101500106

35. Bahraini M, Ziaei A. A model to identify and assess the impact of sports sponsorship on brand value. J Busin Rev. 2011;10(55):26-36 [Article in Farsi].

36. Akroush MN, Dahiyat SE, Gharaibeh HS, Abu-Lail BN. Customer relationship management implementation: An investigation of a scale's generalizability and its relationship with business performance in a developing country context. Int J Commerce Manage. 2011;21(2):158-90. doi: $10.1108 / 10569211111144355$

37.King C, Grace D. Building and measuring employee-based brand equity. Eur J Market. 2010;44(7/8):938-71. doi: 10.1108/03090561011047472

38. Shank MD, Lyberger MR. Sports Marketing: A Strategic Perspective, 5th edition. 5th ed: Taylor \& Francis; 2014. 672 p. 